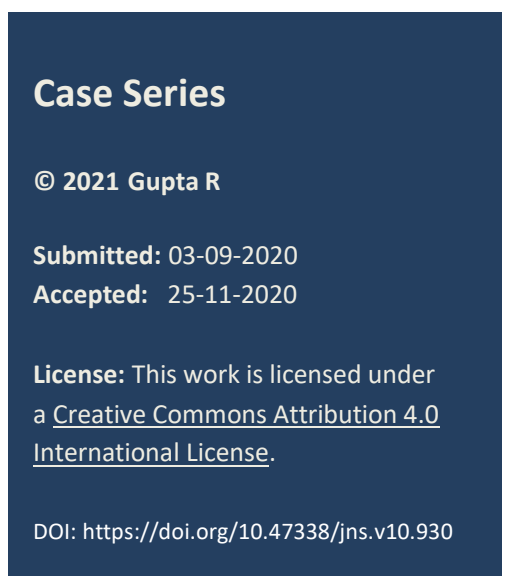

\title{
Spontaneous pneumoperitoneum: Discerning from radiological imaging
}

Rahul Gupta

Department of Paediatric Surgery, SMS Medical College, Jaipur, Rajasthan, India

Correspondence*: Dr. Rahul Gupta, Assistant Professor, Department of Paediatric Surgery, SMS Medical College, Jaipur, Rajasthan India. E-mail: meetsurgeon007@gmail.com

\begin{abstract}
KEYWORDS
Mechanical ventilation,

Neonate,

Rigler sign,

Spontaneous

pneumoperitoneum

\section{ABSTRACT}

Background: Pneumoperitoneum without any gastrointestinal (GI) perforation or peritonitis is entitled spontaneous pneumoperitoneum. We aimed to describe a radiological perspective in spontaneous pneumoperitoneum.

Methods: This case series presented data of 4 cases of spontaneous pneumoperitoneum managed at our institution.

Results: There were 85 patients with a provisional diagnosis of necrotizing enterocolitis (NEC) and/or pneumoperitoneum. Out of these, there were 4 patients with the final diagnosis of spontaneous pneumoperitoneum; three males and 1 female. At presentation, respiratory distress was seen in 3. It was preceded by mechanical ventilation in 3 patients. All 4 had soft abdominal distension, absence of features suggestive of peritonitis, and the presence of free air with an absence of air-fluid level in peritoneal cavity on erect abdominal radiographs. The Rigler sign was present in 3 patients. Abdominocentesis followed by abdominal drain placement was performed in 2 patients. Laparotomy was performed in 1 patient which could not point to any pathology (negative). An unfavorable outcome was seen in one patient with associated esophageal atresia. No patient had any evidence (either ultrasound/radiological or on laparotomy) of leakage of contents from the GI tract.

Conclusions: In infants, especially preterm neonates, presenting with soft abdominal distension with abrupt onset of pneumoperitoneum, without clinical features of peritonitis and preceded by mechanical ventilation, diagnosis of spontaneous pneumoperitoneum should be considered.
\end{abstract}

\section{INTRODUCTION}

Pneumoperitoneum in neonates is classically due to gastrointestinal (GI) perforation.[1] In contrast, pneumoperitoneum without any GI perforation or peritonitis is entitled spontaneous pneumoperitoneum.[1,2] These neonates may improve primarily with conservative management or may require abdominocentesis and/or abdominal drain placement.[3] The author managed 4 cases of spontaneous pneumoperitoneum and is sharing his experience along with a review of radiological findings pertinent to spontaneous pneumoperitoneum

\section{METHODS}

This study was performed from October 2018 to February 2020. The data of 4 cases of spontaneous pneumoperitoneum were analyzed and special em- phasis was put on radiological findings that can differentiate spontaneous from pathological pneumoperitoneum.

All patients were admitted to the intensive care unit. Enteral feeds were stopped and nasogastric tube placement was performed. Intravenous fluids and parenteral nutrition were initiated in all patients along with broad-spectrum antibiotics. Baseline blood investigations including complete blood counts, serum electrolytes, CRP, renal, and liver functions were performed. Abdominal Radiographs, both erect (AP) and supine views were performed, initially 12 hourly for the first 48 hours and then 24 hourly after 48 hours. Additional views including the lateral decubitus view were performed, when required. Ultrasound 
with color Doppler was performed to evaluate the GI pathology i.e., perforation/ gangrenous bow$\mathrm{el} /$ ischemia and associated malformations.

Patients with or without pneumoperitoneum with clinical, laboratory signs and ultrasonography suggestive of perforation or peritonitis were optimized, subjected to exploratory laparotomy, and managed separately. Patients with pneumoperitoneum and without clinical signs suggestive of peritonitis were managed on the lines of spontaneous pneumoperitoneum. All patients were closely observed for the development of signs suggestive of peritonitis. Conservative management was contemplated; abdominocentesis followed by abdominal drain placement was considered in these patients

\section{RESULTS}

Clinical records revealed 85 pediatric patients with a provisional diagnosis of either necrotizing enterocolitis (NEC) and/or pneumoperitoneum due to gastrointestinal (GI) perforation. Out of these, 73 manifested with pneumoperitoneum including 4 patients with spontaneous pneumoperitoneum.

Of these 4 cases, 3 were males and 1 female, and the age of presentation ranged from 1 day to 4 months. Three patients were born preterm. Three patients presented with respiratory distress. One had major malformation i.e., esophageal atresia (EA) Vogt type 3b with retroperitoneal cystic swelling. Presentation of spontaneous pneumoperitoneum was preceded by mechanical ventilation in 3 patients. Two patients were hemodynamically stable at presentation, while poor general condition with hemodynamic instability was present in the other two. Abdominal examination revealed soft distension in all 4 patients. Signs of peritonitis were absent in all the patients. Table 1 showed the clinical profile of these patients.

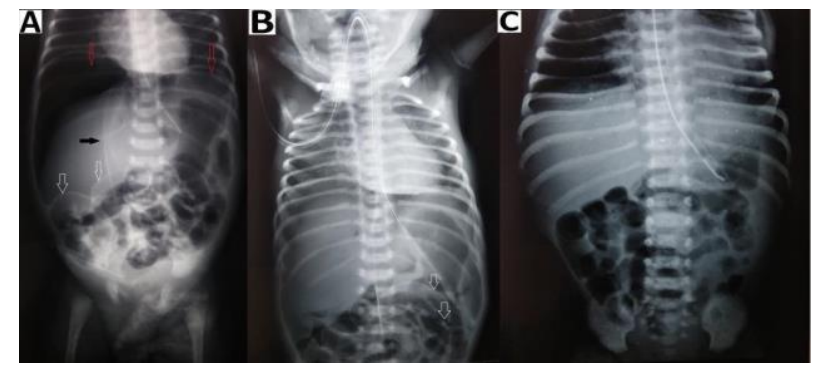

Figure 1: Abdominal radiographs (erect) (A) showing pneumoperitoneum with gas under the diaphragm (red arrows), Rigler sign (white arrows) and outlining of falciparum ligament (black arrow); supine image (B) showing Rigler sign (white arrows); erect image

(C) showing resolution of pneumoperitoneum after abdominal drain placement.

Pneumoperitoneum with air under both the domes of the diaphragm was seen in all 4 patients on erect abdominal radiographs (Fig.1, Fig.2, Fig.3, and Fig.4). There was an absence of free fluid in the peritoneal cavity evident by the absence of air-fluid level in the peritoneal (abdominal) cavity i.e., outside bowel loops in all the patients. Dilated small bowel loops were seen in 3 out of 4 patients. Rigler sign or double-wall sign was present in 3 patients. Radiographic evidence of pneumothorax (simultaneously present with pneumoperitoneum) was seen in 1 patient (Fig.4). Pneumoscrotum was appreciated in 2 patients (Fig. 3 and Fig.4).

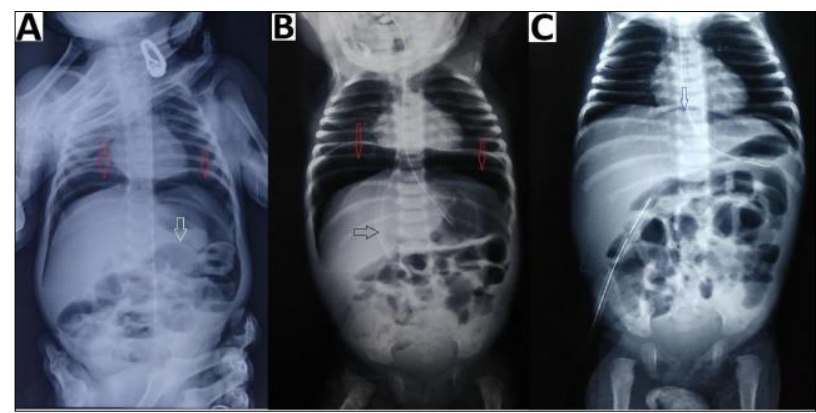

Figure 2: Abdominal radiographs (erect) (A) showing gas under the diaphragm (red arrows), Rigler sign (white arrow); supine image (B) showing pneumoperitoneum (red arrows), outlining of falciparum ligament (black arrow); erect image (C) showing resolution of pneumoperitoneum (blue arrow) with abdominal drain in-situ.

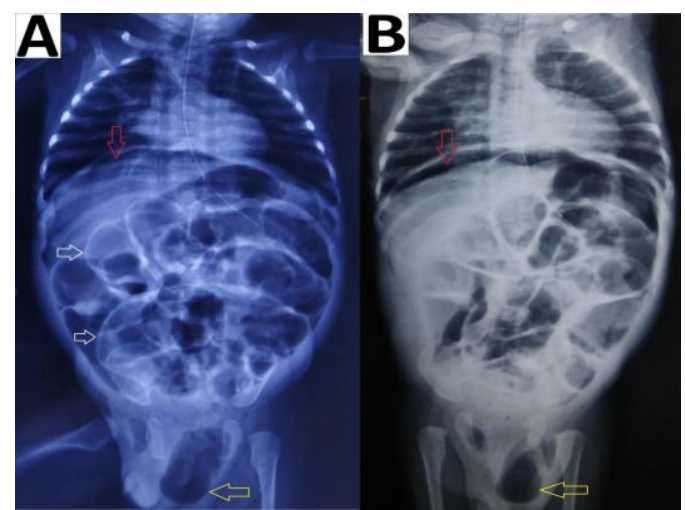

Figure 3: Abdominal radiographs (erect) (A) showing gas under the diaphragm (red arrow), Rigler sign (white arrows); supine image (B) showing pneumoperitoneum (red arrow) and pneumoscrotum (yellow arrow)

C-reactive protein (CRP) was done in 2 patients and was raised in both. In the other two, CRP could not be performed due to resource limitations. Ultrasound was performed in all except in a patient with EA. U1trasound examination didn't suggest any perforation or visceral pathology, apart from the presence of pneumoperitoneum in all 3 patients.

Initial conservative management then abdominocentesis followed by abdominal drain placement was per-formed under ultrasound guidance in 2 patients; these two had favorable outcomes. Laparotomy was performed in 1 patient after initial conservative management for 24 hours. This decision was taken be-cause of raised CRP $(117 \mathrm{mg} / \mathrm{L})$ levels in addition to the diagnostic dilemma in management. It was negative for any perforation and the outcome was favorable. Due to the long-gap EA, esophagostomy and gastrostomy were performed, following transfixation and ligation of trachea-esophageal fistula in one patient. 
Table 1: Clinical details, investigations undertaken, management details, and outcomes of patients with spontaneous

\begin{tabular}{|c|c|c|c|c|}
\hline Patient data & Case 1 & Case 2 & Case 3 & Case 4 \\
\hline Sex & Male & Female & Male & Male \\
\hline Age & 10 days & 34 days & 4 months & 1 day \\
\hline Maturity & Preterm & Term & Preterm & Preterm \\
\hline Weight & $1800 \mathrm{~g}$ & $2300 \mathrm{~g}$ & $1500 \mathrm{~g}$ & $2100 \mathrm{~g}$ \\
\hline Clinical presentation & $\begin{array}{l}\text { Respiratory distress } \\
\text { (48 Hours) } \\
\text { Fever } \\
\text { Increasing Abdominal } \\
\text { distension } \\
\text { Bilious vomiting }\end{array}$ & $\begin{array}{l}\text { Sudden Abdominal } \\
\text { distension } \\
\text { Bilious nasogastric tube } \\
\text { aspirate }\end{array}$ & $\begin{array}{l}\text { Respiratory Tract infec- } \\
\text { tion } \\
\text { Sudden Abdominal } \\
\text { distension } \\
\text { Non-Bilious nasogastric } \\
\text { tube aspirate }\end{array}$ & $\begin{array}{l}\text { Frothing } \\
\text { Drooling of saliva } \\
\text { Respiratory distress } \\
\text { Abdominal distension }\end{array}$ \\
\hline Fever & Afebrile & Afebrile & Afebrile & Afebrile \\
\hline $\begin{array}{l}\text { Associated illness or } \\
\text { malformations }\end{array}$ & $\begin{array}{l}\text { Discolored skin patch } \\
\text { (nevus) on the left ear }\end{array}$ & Nil & Inguinal hernia & $\begin{array}{l}\text { EA type 3b (long gap) } \\
\text { Cardiac murmur } \\
\text { Retroperitoneal cystic } \\
\text { swelling }\end{array}$ \\
\hline Meconium passed & Within 24 hours & Within 24 hours & Within 24 hours & Within 24 hours \\
\hline $\begin{array}{l}\text { Mechanical ventilation } \\
\text { Before the presentation }\end{array}$ & Yes & No & $\begin{array}{l}\text { Yes } \\
\text { CPAP }\end{array}$ & $\begin{array}{l}\text { Yes } \\
\text { High flow oxygen } \\
\text { AMBU support }\end{array}$ \\
\hline General Condition & $\begin{array}{l}\text { Poor } \\
\text { Respiratory distress } \\
\text { Mild dehydration }\end{array}$ & Stable & Stable & $\begin{array}{l}\text { Poor } \\
\text { Respiratory distress } \\
\text { Ventilatory support }\end{array}$ \\
\hline Abdominal examination & $\begin{array}{l}\text { Soft } \\
\text { Moderate Distension }\end{array}$ & Soft Distension & $\begin{array}{l}\text { Soft, but } \\
\text { Marked } \\
\text { Distension }\end{array}$ & Soft Distension \\
\hline Pneumoperitoneum & $\begin{array}{l}\text { Present } \\
\text { (both domes, right }>\text { left) }\end{array}$ & Present (both domes) & $\begin{array}{l}\text { Present } \\
\text { (both domes, right > left) }\end{array}$ & Present (both domes) \\
\hline $\begin{array}{l}\text { Large Air-fluid level in } \\
\text { peritoneal cavity out- } \\
\text { side bowel loops }\end{array}$ & Absent & Absent & Absent & Absent \\
\hline $\begin{array}{l}\text { Dilated small bowel } \\
\text { loops }\end{array}$ & Present & Present & Present & Absent \\
\hline Multiple Air-fluid levels & Absent & Absent & Absent & Absent \\
\hline Rigler sign & $\begin{array}{l}\text { Present } \\
\text { Figure } 1\end{array}$ & $\begin{array}{l}\text { Present } \\
\text { Figure } 2\end{array}$ & $\begin{array}{l}\text { Present } \\
\text { Figure } 3\end{array}$ & $\begin{array}{l}\text { Absent } \\
\text { Figure } 4\end{array}$ \\
\hline Pneumothorax & Absent & Absent & Absent & Present \\
\hline Pneumoscrotum & Absent & Absent & Present & Present \\
\hline Pneumonitis & Present & $\mathrm{Nil}$ & Present & Present \\
\hline $\begin{array}{l}\text { CRP } \\
\text { Other Investigations }\end{array}$ & $\begin{array}{l}\text { Not done } \\
\text { Platelets } 42,000 / \mathrm{mm}^{3}\end{array}$ & $\begin{array}{l}\text { Positive }(42 \mathrm{mg} / \mathrm{L}) \\
\text { Platelets } 71,000 / \mathrm{mm}^{3} \\
\text { TLC } 23,100 / \mathrm{mm}^{3}\end{array}$ & $\begin{array}{l}\text { Positive }(117 \mathrm{mg} / \mathrm{L}) \\
\text { Hypoproteinemia } \\
\text { TLC } 13,500 / \mathrm{mm}^{3}\end{array}$ & Not done \\
\hline Ultrasound abdomen & $\begin{array}{l}\text { Dilated bowel loops } \\
\text { Pneumoperitoneum }\end{array}$ & $\begin{array}{l}\text { Dilated bowel loops } \\
\text { Pneumoperitoneum }\end{array}$ & $\begin{array}{l}\text { Dilated bowel loops } \\
\text { Pneumoperitoneum }\end{array}$ & Not done \\
\hline Provisional Diagnosis & NEC & NEC & $\begin{array}{l}\text { NEC } \\
\text { Perforation peritonitis }\end{array}$ & $\begin{array}{l}\text { EA type 3b } \\
\text { Spontaneous } \\
\text { Pneumoperitoneum }\end{array}$ \\
\hline Procedures performed & $\begin{array}{l}\text { Abdominal drain } \\
\text { placement only (Diag- } \\
\text { nostic \& therapeutic) }\end{array}$ & $\begin{array}{l}\text { Abdominal drain } \\
\text { placement only (Diag- } \\
\text { nostic \& therapeutic) }\end{array}$ & $\begin{array}{l}\text { Laparotomy } \\
\text { No evidence of any intra- } \\
\text { abdominal pathology }\end{array}$ & $\begin{array}{l}\text { Primary repair of EA } \\
\text { failed; chest tube } \\
\text { Esophagostomy } \\
\text { Gastrostomy } \\
\text { No evidence of perfora- } \\
\text { tion } \\
\text { Abdominal drain } \\
\text { placement }\end{array}$ \\
\hline $\begin{array}{l}\text { Content of peritoneal } \\
\text { cavity }\end{array}$ & Air-only & Air-only & Air-only & Air-only \\
\hline $\begin{array}{l}\text { Pneumoperitoneum to } \\
\text { disappear }\end{array}$ & 2 days & 4 days & $5^{\text {th }}$ day postoperatively & - \\
\hline $\begin{array}{l}\text { Postoperative Ultra- } \\
\text { sound abdomen }\end{array}$ & $\begin{array}{l}\text { Minimal free fluid } \\
\text { Normal bowel loops } \\
\text { No air bubbles }\end{array}$ & $\begin{array}{l}\text { Fluid-filled dilated bowel } \\
\text { loops } \\
\text { Slight air bubbles noted in } \\
\text { the interlobar fissure of } \\
\text { the liver } \\
\text { Bowel wall edema pre- } \\
\text { sent }\end{array}$ & $\begin{array}{l}\text { Not done (as laparotomy } \\
\text { was performed) }\end{array}$ & $\begin{array}{l}\text { Not done (Postoperative } \\
\text { mortality) }\end{array}$ \\
\hline Oral feeds & $4^{\text {th }}$ day & $3^{\text {rd }}$ day & $3^{\text {rd }}$ day & - \\
\hline Discharge & $5^{\text {th }}$ day & $4^{\text {th }}$ day & $7^{\text {th }}$ day & Mortality \\
\hline Outcome & Favorable & Favorable & Favorable & Unfavorable \\
\hline $\begin{array}{l}\text { Cause of Unfavourable } \\
\text { outcome }\end{array}$ & - & - & - & $\begin{array}{l}\text { Sepsis, Cardiac anoma- } \\
\text { lies }\end{array}$ \\
\hline
\end{tabular}




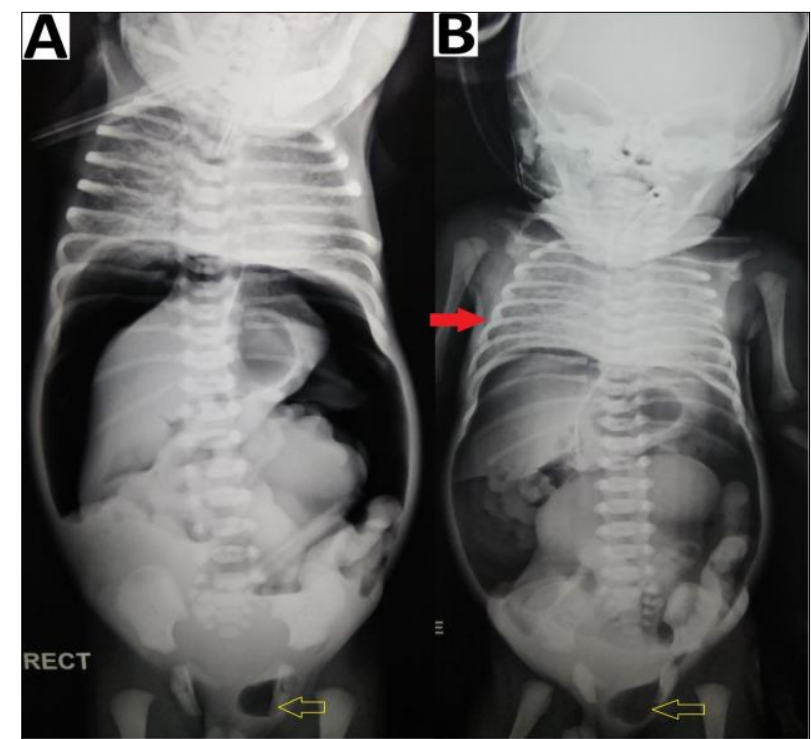

Figure 4: Abdominal radiographs (erect) (A) showing gas under the diaphragm, absence of gas-filled bowel loops, endotracheal tube in-situ, and features of pneumonitis; supine image (B) also showing pneumothorax (red arrow). Pneumoscrotum (yellow arrow) is appreciable in both images (A and B)

Laparotomy revealed free air but the etiology of which could not be identified. This patient had an unfavorable outcome purported to be due to associated cardiac anomalies and severe sepsis. No patient had any evidence of leakage of GI contents, either radiological or on insertion of abdominal drain/laparotomy. No patient had a recurrence of the pneumoperitoneum in follow up ( 3 months to 1 year) and doing well.

\section{DISCUSSION}

Pneumoperitoneum in a neonate is classically due to GI perforation and necrotizing enterocolitis (NEC).[3,4] Pneumoperitoneum is usually diagnosed by an erect abdominal radiograph showing free air under the domes of the diaphragm. In the neonates the other radiographic signs include, (a) rounded or oval lucency over the upper abdomen in the supine position, (b) increased lucency i.e. triangular or a semilunar collection of air anterior to the abdominal viscera or above the liver in lateral decubitus position, (c) large volume of free air may give rise to the football sign, where the air outlines the whole of the peritoneal cavity and under the surface of the diaphragm, (d) the lacing of the football i.e. outlining of falciparum ligament of the liver against the radiolucency of free abdominal air on supine view [4,5,6] (e) Rigler sign or double-wall sign is free gas on both sides of the bowel wall,[4,5] (f) pneumoscrotum has been explained due to presence of patent processus vaginalis and passage of air from the peritoneal cavity into the scrotum. $[3,5,6]$

The clinical findings in pneumoperitoneum secondary to NEC or neonatal GI perforation include features of peritonitis, tense abdominal distension, palpable, distended bowel loops, shiny red induration of abdominal wall, tenderness, muscle stiffness, guarding, shifting dullness, and absent (decreased) bowel sounds.[3,7] Besides, systemic features of sepsis, like fever and toxemia are present (Table 2). These features are insidious in onset and progressive in nature and categorized as surgical pneumoperitoneum and an urgent laparotomy is mandatory to improve the outcome.[1,3,4]

In patients with NEC or other GI pathologies, the presence of significant intraperitoneal fluid in the abdominal cavity on radiographs is seen as gas-filled loops of bowel which float centrally in the abdomen.[5] Ultrasound is a more specific investigation for the diagnosis of intraperitoneal fluid.[5] Ultrasound with color Doppler can access bowel wall thickness, echogenicity, peristalsis, perfusion, and bowel viability.[4]

Visualization of pneumatosis intestinalis on radiographs and/or on ultrasound with underlying clinical features is suggestive of NEC. A linear or crescent type is more specific than a bubbly or foamy gas pattern.[5] Demonstration of fixed bowel loop sign and portal venous gas is diagnostic of NEC. The presence of a large air-fluid level in the peritoneal cavity with ground-glass opacity in the lower abdomen along with an absence of gas-filled dilated bowel loops is highly suggestive of pneumoperitoneum due to hollow viscus perforation.[5]

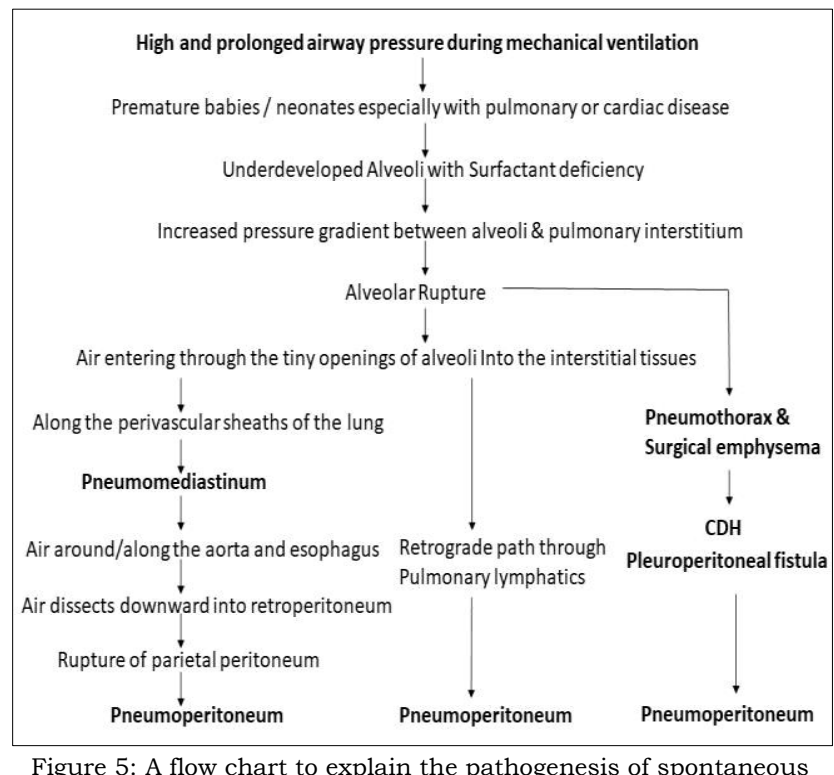

Figure 5: A flow chart to explain the pathogenesis of spontaneous pneumoperitoneum in pediatric patients

Pneumoperitoneum in a pediatric patient especially premature neonate with soft abdominal distension, without clinical features suggestive of perforation peritonitis/ NEC (as described above) and preceded by mechanical ventilation and is known as non-surgical, 
asymptomatic, benign, misleading, medical, idiopathic, or spontaneous pneumoperitoneum. It is also occasionally called CPAP (Continuous Positive Airway Pressure) belly syndrome.[1-5] The condition is rare in clinical practice.[1-5] In our study, it was seen in $5.48 \%$ (4) patients out of 73 cases of pneumoperitoneum. In addition to lack of definite causes (NEC, gut perforation, etc.), there is usually the absence of systemic features like fever and toxemia, though these features could be due to the presence of associated malformations as seen in $50 \%$ of patients in our study (Table 2).

In case of spontaneous pneumoperitoneum, the onset is abrupt usually following mechanical ventilation.[13] The pathogenesis of spontaneous pneumoperitoneum is an air-leak from the lungs as shown in the flowchart (Fig.5). This is more common with high and prolonged airway pressure during mechanical ventilation or CPAP. In our study, the condition was preceded by mechanical ventilation in $75 \%$ (3), while it was $55.56 \%$ in our previous study.[3] The presence of pneumothorax (as seen in one of our cases) or pneumomediastinum immediately before or simultaneously with pneumoperitoneum is an indicator of spontaneous pneumoperitoneum. $[3,10]$

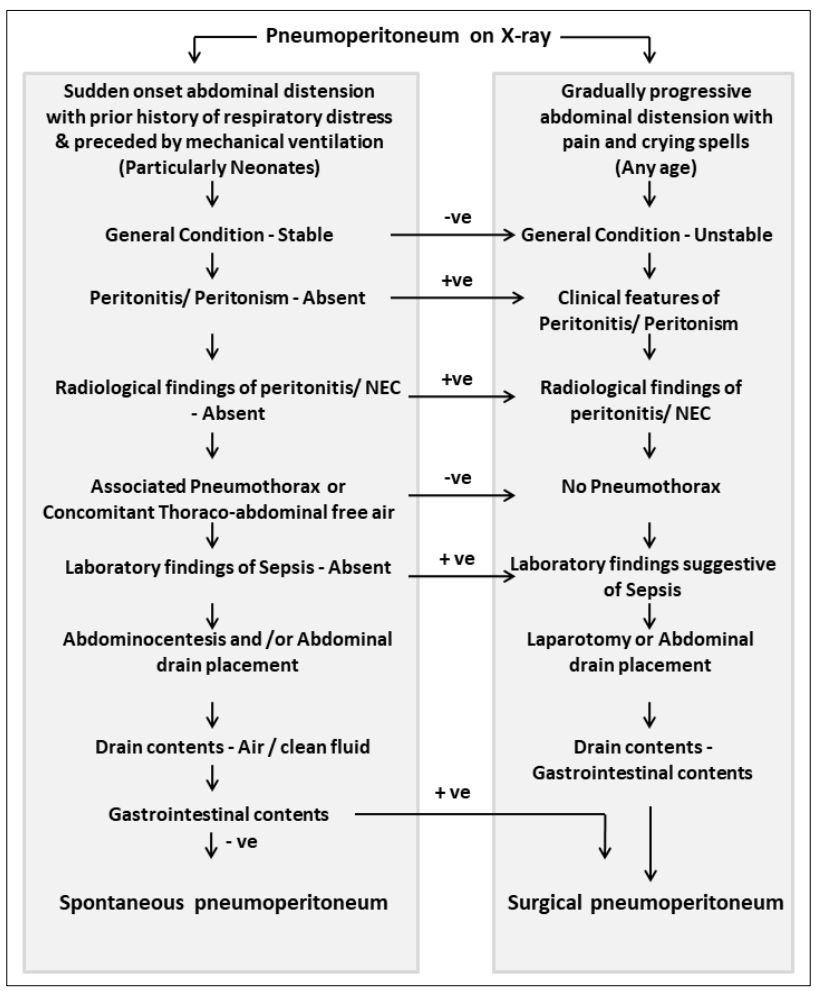

Figure 6: Algorithm for the pneumoperitoneum

Before labeling a patient with spontaneous pneumoperitoneum, other causes like NEC, spontaneous intestinal perforation (SIP), gastric perforation, and perforations as a complication of neonatal intestinal obstruction should be ruled out. A comprehensive clinical evaluation with frequent abdominal examination for ruling out peritonitis, laboratory workup for ruling out sepsis, radiological evaluation for the presence of pneumonitis, pneumothorax (or pneumomediastinum), and abdominal ultrasonography should be performed.

Management comprises of stabilization of the patient, nil per oral along with close surveillance for signs suggestive of peritonitis and/or systemic signs.[1,3] Conservative management is contemplated and may be successful in 33.33\% of patients.[3] Abdominocentesis followed by abdominal drain placement (continuous evaluation of the peritoneal contents) is diagnostic and therapeutic (relieving respiratory embarrassment due to splinting of the diaphragm). It also confirms the presence of free air and rules out leakage of GI contents.[3] Abdominocentesis or abdominal taping has been therapeutic in other studies.[7] Unnecessary laparotomy could be avoided in $50 \%$ of patients in our study. Complete resolution of pneumoperitoneum may take 2 to 10 days, which was a similar finding (2 to 5 days) in our study. [3] The algorithm for the management of spontaneous pneumoperitoneum is explained in Fig. 6.

\section{CONCLUSION}

Spontaneous pneumoperitoneum is a rare entity in patients admitted with a provisional diagnosis of pneumoperitoneum in the neonatal period and/or NEC with pneumoperitoneum. In preterm neonates having major congenital malformations presenting with soft abdominal distension with abrupt onset of pneumoperitoneum without clinical features of peritonitis and preceded by mechanical ventilation, the diagnosis of spontaneous pneumoperitoneum should be considered. An unnecessary laparotomy that increases morbidity and mortality can be avoided in patients of spontaneous pneumoperitoneum with a high index of suspicion.

Acknowledgements: Nil

Conflict of Interest: None

Source of Support: Nil

Consent to Publication: Author(s) declared taking informed written consent for the publication of clinical photographs/material (if any used), from the legal guardian of the patient with an understanding that every effort will be made to conceal the identity of the patient, however it cannot be guaranteed.

Author Contributions: Author(s) declared to fulfil authorship criteria as devised by ICMJE and approved the final version. 
Table 2: Differences between spontaneous pneumoperitoneum and pneumoperitoneum due to bowel perforation (surgical pneumoperitoneum).

\begin{tabular}{|c|c|c|c|}
\hline $\begin{array}{l}\text { Clinical Laboratory \& } \\
\text { Radiological Characteristics }\end{array}$ & Specific characteristics & $\begin{array}{l}\text { Surgical pneumoperito- } \\
\text { neum }\end{array}$ & Spontaneous pneumoperitoneum \\
\hline \multirow{9}{*}{ Clinical Characters } & Age group & All & $\begin{array}{l}\text { Neonates (Newborn) especially with } \\
\text { prematurity, LBW }\end{array}$ \\
\hline & Abdominal distension & Present & $\begin{array}{l}\text { Present (Sudden Abdominal } \\
\text { distension at admission or later) }\end{array}$ \\
\hline & Pain & Present & Absent \\
\hline & Onset & Gradually progressive & Sudden onset \\
\hline & $\begin{array}{l}\text { Prior history of respiratory } \\
\text { distress }\end{array}$ & Usually absent & $\begin{array}{l}\text { Usually present } \\
\text { RDS, pneumonia (tachypnea) }\end{array}$ \\
\hline & $\begin{array}{l}\text { Preceded by mechanical ven- } \\
\text { tilation }\end{array}$ & Absent & Present (CPAP, Pressure support) \\
\hline & Associated malformations & Absent & Usually present \\
\hline & General condition & Unstable & Usually stable \\
\hline & Toxaemia (systemic signs) & Present & Absent \\
\hline \multirow{7}{*}{ Abdominal Examination } & Abdominal wall & $\begin{array}{l}\text { Shiny, red, oedematous, } \\
\text { induration }\end{array}$ & Normal \\
\hline & $\begin{array}{l}\text { Abdominal Swelling or } \\
\text { Palpable distended bowel loops }\end{array}$ & Usually present & Absent \\
\hline & Distension & Tense distension & $\begin{array}{l}\text { Soft distension with relaxed } \\
\text { abdominal wall }\end{array}$ \\
\hline & Tenderness (peritonitis) & Present & Non-tender \\
\hline & $\begin{array}{l}\text { Rebound tenderness } \\
\text { Muscle guarding }\end{array}$ & Present & Absent \\
\hline & Shifting dullness & Present & Absent \\
\hline & Bowel sounds & $\begin{array}{l}\text { Absent } \\
\text { Decreased }\end{array}$ & Normal \\
\hline Cardiovascular Examination & Cardiovascular instability & Usually present & Usually absent \\
\hline \multirow{5}{*}{ Abdominal Radiographs } & $\begin{array}{l}\text { Large Air-fluid level in peritoneal } \\
\text { (abdominal) cavity outside bowel } \\
\text { loops (erect) }\end{array}$ & Present & Absent \\
\hline & Dilated small bowel loops & Usually absent & Usually present \\
\hline & $\begin{array}{l}\text { Multiple Air-fluid levels in small } \\
\text { intestinal loops (erect) }\end{array}$ & May be present & Usually absent \\
\hline & $\begin{array}{l}\text { Ground glass opacity in the } \\
\text { lower abdomen (erect) }\end{array}$ & Present & Absent \\
\hline & Rigler sign & May or may not be present & Usually present \\
\hline \multirow[t]{3}{*}{ Chest Radiographs } & Pneumothorax & Absent & $\begin{array}{l}\text { May be present. } \\
\text { (immediately before, simultane- } \\
\text { ously, or after the resolution of } \\
\text { pneumoperitoneum) }\end{array}$ \\
\hline & Pneumomediastinum & Absent & May be present \\
\hline & Pneumonitis & Absent & May be present \\
\hline \multirow{2}{*}{$\begin{array}{l}\text { Ultrasound abdomen with } \\
\text { Colour Doppler }\end{array}$} & Free fluid & Echogenic & Minimal \\
\hline & $\begin{array}{l}\text { Ischemic bowel (decreased } \\
\text { perfusion) }\end{array}$ & Present & Absent \\
\hline \multirow{3}{*}{$\begin{array}{l}\text { Signs suggestive of NEC on } \\
\text { previous radiological imaging } \\
\text { films (Ultrasound abdomen } \\
\text { and/or Radiographs) }\end{array}$} & Portal venous gas & Present & Absent \\
\hline & Pneumatosis intestinalis & Present & Absent \\
\hline & Fixed bowel loops & Present & Absent \\
\hline \multirow[t]{3}{*}{ Laboratory findings } & CRP & Positive (markedly raised) & Usually mildly raised \\
\hline & Thrombocytopenia & Usually present & Usually absent \\
\hline & Polymorpho-leucocytosis & Usually present & Usually absent \\
\hline $\begin{array}{l}\text { Abdominocentesis and /or } \\
\text { Abdominal drain placement }\end{array}$ & Contents of the peritoneal cavity & Air and gastrointestinal fluid & $\begin{array}{l}\text { Air-only } \\
\text { Minimal clear fluid }\end{array}$ \\
\hline Management & Surgical procedure & Laparotomy & Conservative \\
\hline
\end{tabular}




\section{REFERENCES}

1. Duan SX, Sun ZB, Wang GH, Zhong J, Ou WH, Fu MX, et al. Diagnosis and treatment of pediatric benign pneumoperitoneum: A case report series of 9 patients. Medicine. 2017; 96:e5814.

2. Gupta R, Bihari Sharma S, Golash P, Yadav R, Gandhi D. Pneumoperitoneum in the newborn: Is surgical intervention always indicated? J Neonatal Surg. 2014; 3:32.

3. Gupta R. Spontaneous pneumoperitoneum in pediatric patients: Dilemmas in Management. $\mathrm{J}$ Indian Assoc Pediatr Surg. 2018; 23:115-22.

4. Epelman M, Daneman A, Navarro OM, Morag I, Moore AM, Kim JH, et al. Necrotizing enterocolitis: Review of state-of-the-art imaging findings with pathologic correlation. RadioGraphics. 2007; 27:285-305.

5. Morrison SC, Jacobson JM. The radiology of necrotising enterocolitis. Clinics in Perinatol. 1994; 21:347-63.
6. Prasad GR, Aziz A. Abdominal plain radiograph in neonatal intestinal obstruction. J Neonatal Surg. 2017; 6:6. Available from: https://doi.org/10.21699/jns.v6i1.483.

7. Pandey A, Singh SP, Gupta V, Verma R. Conservative management of pneumoperitoneum in necrotising enterocolitis- is it possible? J Neonatal Surg. 2016; 5:12.

8. Čečka F, Šubrt $Z$, Sotona O. How to distinguish between surgical and non-surgical pneumoperitoneum? Signa Vitae. 2014; 9:9-15.

9. Gopagondanahalli KR, Si Min SG, Chandran S, Sai Prasad TR. Do pneumoperitoneum in a stable extreme low-birth-weight infant always need laparotomy? A clinical conundrum. Med J DY Patil Vidyapeeth 2020; 13:564-6.

10. Bakal U, Aydin M, Orman A, Taskin E, Kazez A. A nonsurgical condition of neonatal pneumoperitoneum: retroperitoneal free air secondary to massive tension pneumothorax. J Med Cases. 2016; 7:13-4. 